\title{
Relationship between the animal body condition and reproduction: the biotechnological aspects
}

\author{
Jiří Bezdíček $^{1}$, Andrea Nesvadbová ${ }^{1}$, Alexander Makarevich ${ }^{2}$, and Elena Kubovičová ${ }^{2}$ \\ ${ }^{1}$ Faculty of Science, Palacký University Olomouc, Olomouc, 771 47, Czech Republic \\ ${ }^{2}$ National Agricultural and Food Centre (NPPC), Research Institute for Animal \\ Production Nitra, 95141 Lužianky, Slovak Republic \\ Correspondence: Jiří Bezdíček (jiri.bezdicek@upol.cz)
}

Received: 5 December 2019 - Revised: 22 April 2020 - Accepted: 12 May 2020 - Published: 1 July 2020

\begin{abstract}
The aim of this review was to evaluate the relationship between the body condition of cows and reproduction. Reproduction was evaluated from the viewpoint of animal husbandry traits, ovarian activity and embryo transfer. Main emphasis was given to the review of articles from the area of biotechnical methods (in vitro embryo production, embryo transfer). Most authors agree on the opinion that the worsening of the reproduction traits of cows is a result of changes in the body condition score (BCS) either under or over their average value. Worsening of reproduction traits was presented not only from a zootechnical viewpoint (e.g., calving interval, $56 \mathrm{~d}$ nonreturn rate, etc.) but also in term of ovarian activity, oocyte recovery and in vitro embryo production. In general, the body condition of cows is an important factor affecting female reproduction ability at the ovarian level.
\end{abstract}

\section{Introduction}

Animal body condition is a crucial factor closely related to many traits, such as reproduction, health, production (e.g., milk) and others. In general, when animals live in a suitable environment, the body condition does not change significantly during the year. A specific situation occurs in dairy cows with various intensity of milk production during lactation, which is reflected in different energy demands. Thus, the body condition of dairy cows can change considerably during one calving interval (period between two births; lactation plus dry period). High energy demands occur in cows during the postpartum period, when milk production intensifies and body fat and energy reserves drop. This period of high milk production is also associated with forthcoming pregnancy. A decrease in the body condition score (BCS) during the postpartum period has been documented by several authors (Roche et al., 2007; Koenen et al., 2001; Friggens et al., 2004). Particularly, Bastin et al. (2010) proved a decrease in BCS during the first part of lactation in Canadian Holstein and Ayrshire cows and the lowest BCS for both breeds after about $60 \mathrm{~d}$ in milk. Buckley et al. (2003) also reported that in the period between calving and first service the body condition score declined dramatically. At the same time, these authors state that the BCS should not fall by more than 0.5 units to avoid a negative effect on reproduction traits. In this regard, the authors also found that a substantial reduction in the body condition is associated with a lower pregnancy rate after $42 \mathrm{~d}$ (Buckley et al., 2003).

Research on the relationship between the body condition and reproduction has been carried out by a number of research teams and from different viewpoints. Important studies have been focused on animal husbandry (Buckley et al., 2003; Berry et al., 2003; Banos et al., 2007; Cam et al., 2018; Gruber et al., 2018; Makarevich et al., 2018; Ledinek et al., 2019; Ptáček et al., 2017; Tančin et al., 2018), but also on biotechnology, e.g., embryo transfer (Bezdíček et al., 2015; Bezdíček and Louda, 2016), in vitro fertilization (Makarevich et al., 2012b; Chrenek et al., 2015; Oba et al., 2013) and ovarian activity (Makarevich et al., 2012a; Kuźnicka et al., 2016). A number of studies have been also focused on the relationship between the body condition and reproduction from a veterinary point of view, e.g., early embryonic mortality and retained placenta (Qu et al., 2014; Aungier et al., 2014; Berry et al., 2007a, b). A relationship 
was also determined between BCS and mastitis by Loker et al. (2012), who calculated the average genetic correlation between the BCS and mastitis in Canadian Holstein $(-0.730)$ and the correlation between BCS and metabolic disease $(-0.438)$. These authors reported a higher susceptibility to mastitis in cows with a lower BCS (Loker et al., 2012).

The worsening of the body condition is thus associated with a number of important breeding aspects. The aim of this review is to evaluate the relationship between the body condition and reproduction in cows from different viewpoints: (1) animal husbandry, (2) ovarian activity and the subsequent production of oocytes and embryos, and (3) embryo transfer in dairy cows. The greatest attention is devoted to ovarian activity.

\section{The system of body condition score (BCS)}

At present, an evaluation of a cow's body condition is carried out very effectively using the body condition score (BCS) system based on a five-point (or different, e.g., nine-point) scale. This system allows a subjective evaluation of the body condition and also a subsequent statistical evaluation of the obtained values. For example, in the case of a five-point scale in Holstein dairy cows, score 1 means a severe undercondition, 3 means an optimal condition and 5 a severe overcondition (Wildman et al., 1982; Edmonson et al., 1989; Ferguson et al., 1994). This evaluation is subjective, and therefore the experience of evaluators plays an important role. Thus, there are efforts to develop an objective system of BCS evaluation (Spoliansky et al., 2016; Azzaro et al., 2011; Ferguson et al., 2006). These systems use different types of cameras, not only digital (Bercovich et al., 2013; Bewley et al., 2008) but also thermal cameras (Halachmi et al., 2008).

Currently, the objective evaluation systems are significantly advanced from 2D to 3D (three-dimensional) visualization, allowing for monitoring the animal contours as well (Weber et al., 2014; Shelley et al., 2016; Hansen et al., 2018; Shigeta et al., 2018). There are numerous three-dimensional systems nowadays, but the important thing is to consider their applicability to different cattle breeds. According to Alvarez et al. (2018) it would be appropriate to analyze these parameters specifically for each cattle breed.

\section{Body condition of cows from the viewpoint of animal husbandry}

Generally, reproduction in cows is evaluated from different viewpoints. Animal husbandry observes the following traits: age at first calving, days between first service and conception, $56 \mathrm{~d}$ nonreturn rate at first insemination, length of calving interval, number of inseminations per lactation, and other reproduction indicators that have been analyzed in a number of studies in the past years in relation to various influences, including body condition.

These animal husbandry indicators (traits) are very important and understandable in practice, but they are generally influenced by a number of external or internal factors. For this reason, reproduction research has currently moved into the field of gametes, ovarian activity and embryo production where reproduction begins. Research at this level has enabled the development of biotechnical methods in cattle breeding, especially embryo transfer, in vitro fertilization and embryo culture, as well as technical equipment, e.g., sonography and micromanipulation with gametes.

Most authors agree on the negative genetic correlation between reproduction and BCS in animal husbandry traits. In particular, Bastin et al. (2010) reported negative genetic correlations between BCS and days from calving to first service, days from first service to conception, and open days. For Holstein cows these correlations ranged between -0.31 and -0.03 . Positive correlations were found between BCS and a $56 \mathrm{~d}$ nonreturn rate at first insemination (Bastin et al., 2010). Based on these results, the authors concluded that in Holstein and Ayrshire cows, a genetically low BCS at early lactation is connected with a longer nonpregnant time and a lower chance of pregnancy after the first service. Similarly, Berry et al. (2003) presented a genetic correlation between BCS and the interval to first services that ranged from -0.47 to -0.31 . The correlation between BCS and fertility has been determined in a number of studies (Chebel et al., 2018; Pryce et al., 2001, 2002; Dechow et al., 2001; 2002; Gillund et al., 2001; Domecq et al., 1997; Banos et al., 2007). Many studies also emphasize the nonlinearity of these relationships (Tiezzi et al., 2013).

\section{Body condition of cows from the viewpoint of embryo transfer}

In the past years, embryo transfer has become a mastered biotechnology method in cattle. This biotechnique has enriched the research with very important knowledge about a number of factors affecting animal reproduction. These are factors such as temperature stress, the effect of an individual (due to the large number of offspring) and the effect of the lactation stage. The results of embryo production (embryo transfer) were also evaluated in terms of animal body condition.

In this field, Bezdíček et al. (2015) reported that better results in embryo transfer were achieved in Holstein cows with an optimal body condition (BCS 3.0-3.5) than in cows with a tendency to obesity or emaciation. Specifically, the animals divided into three groups according to their body condition (BCS less than 2.9, 3.0-3.5 and above 3.5 points) produced an average number of flushed embryos per flushing as follows: $3.4( \pm 0.690), 4.6( \pm 0.917)$ and $1.9( \pm 1.659)$ pieces, respectively. Also, in terms of embryo quality (transferable 
or degenerated) better results were obtained in cows with an optimal body condition. In the studied BCS groups the following results for the number of transferable (pieces) and the proportion of degenerated embryos (\%) were obtained: BCS up to 2.9 (2.58 pieces and 31.05\%), BCS 3.0-3.5 (3.41 pieces and $28.31 \%)$ and BCS over 3.5 (1.66 pieces and $19.07 \%)$, respectively. However, the differences among the groups were statistically insignificant (Bezdíček et al., 2015).

Relationships between fertility and changes in body weight (BCS) were also the subject of the study by Carvalho et al. (2014). The authors divided the cows at the postpartum period into four quartiles $(\mathrm{Q})$ that presented changes $(\%)$ in body weight $(\mathrm{Q} 1$ indicates the smallest change; $\mathrm{Q} 4$ indicates the biggest change). Comparison of groups Q1 and Q4 revealed a higher proportion of transferable embryos $(83.8 \%$ vs. $53.2 \%)$ and a lower proportion $(9.6 \%$ vs. $35.2 \%)$ and count $(0.6 \%$ vs. $2.7 \%)$ of degenerated embryos in the Q1 group (smallest change). In conclusion, the authors concluded that these results are in compliance with the idea that a lower BCS at the time of the first insemination is associated with fertility decline (Carvalho et al., 2014).

The relationship between embryonic losses in dairy cows was studied by Silke et al. (2002). The authors state that changes in BCS in dairy cows are connected with embryonic mortality. It was found that a higher rate of embryonic loss $(11.6 \%)$ is associated with a decline in BCS during 28-56 gestation days. With a change in the body condition by -1 point, the regression of embryo loss was 0.211 ; in the case of an unchanged body condition or change by +1 point, the probability of embryo loss in cows was 0.065 or 0.018 (Silke et al., 2002).

Kadokawa et al. (2008) studied the relationship between BCS and embryo production in Holstein heifers (Iwate Station, Japan). In this study concentrations of insulin and glucose were also determined. The results showed that heifers with BCS 3.5 showed a lower count of flushed excellent embryos and total number of embryos than heifers with BCS 3.00 or 3.25 . Heifers with BCS 2.75 tended ( $p=0.06$ ) to produce more unfertilized oocytes than heifers with the body condition score 3.25 . The results also showed that heifers with BCS 3.5 were hyperinsulinemic (blood insulin concentration was $155.8 \pm 14.0 \mathrm{pM}$ ), while in heifers with BCS 2.75 the insulin concentration was $125.6 \pm 15.1 \mathrm{pM}$ (Kadokawa et al., 2008).

In general, cows (or heifers) with excellent results in milk production are used for embryo transfer. This technique is mostly carried out at the best farms, and therefore it is highly unlikely to find animals with a poor body condition at extreme values (BCS 1 and 5). In principle, these animals are not used for embryo transfer. Nevertheless, in practice there is an obvious tendency and recommendation to use animals at an optimal body condition (BCS 3 ) for embryo transfer.

In recent years, research in this area has focused not only on monitoring the number of obtained embryos or their quality, but also on ovarian activity, such as the number of cor- pus luteum, the size of the dominant follicle and the size of the ovary. Thus, research on body condition influence is focused on ovarian activity (Boland et al., 2001; Makarevich et al., 2011; Sirotkin et al., 2013).

\section{Body condition of cows from the viewpoint of ovarian activity, oocyte recovery and embryo production in vitro}

A healthy and functional corpus luteum is very important for optimal reproduction. A number of research papers in this field demonstrate that animals with a poor body condition (thin or fat cows) evidence changes in histopathological images of corpus luteum. This is associated with decreased progesterone production. In particular, Makarevich et al. (2012a) found that the average number of active corpora lutea (determined postmortem) was lower in animals with a lower body condition (BCS 1) than in animals with an optimal body condition (BCS 3). This also corresponded to the number of detected corpus albicans. Specifically, the numbers of corpus luteum in BCS 1 vs. BCS 3 were 0.19 vs. 0.37 pieces, respectively; in the case of corpus albicans it was 0.25 vs. 0.38 pieces, respectively. These differences were statistically significant. These authors also reported that no significant differences in the mean ovary area between cows of different BCS groups (BCS 1, BCS 3, BCS 4: 9.40, 7.74, $8.14 \mathrm{~cm}^{2}$ ) were observed (Makarevich et al., 2012a). The size of the ovarian area was also studied by Sirotkin et al. (2013), who reported a smaller ovarian area in emaciated cows (BCS 2) compared to cows with the optimal body condition (BCS 3).

Murphy et al. (1991) found that low dietary intake in beef heifers is associated with a smaller diameter of dominant follicles during the oestrous cycle. The maximum diameter of dominant follicles was significantly smaller $(11.8 \pm 0.1 \mathrm{~mm})$ in the case of low diet (feeding $0.7 \%$ of body weight in dry matter) in comparison with the heifers fed $1.1 \%$ or $1.8 \%$ of their body weight in dry matter. In this case the diameter of dominant follicles was $13.7 \pm 0.2$ or $13.2 \pm 0.3 \mathrm{~mm}$, respectively (Murphy et al., 1991).

Beam and Butler (1997) also found that higher fat intake is linked to an increased diameter of dominant follicles. The authors present evidence that cows with a moderate-fat or highfat diet generate a greater number of follicles $(>15 \mathrm{~mm})$ compared to cows with a low-fat diet.

A poor body condition (mainly BCS 1 ) in cows may even result in the malfunction of ovarian activity in the form of cystic atresia of ovarian follicles (Pivko et al., 2012). Thus, the ratio of cystic atresia increased in the case of emaciated cows (BCS 1 and 2) in comparison to cows with an optimal body condition (BCS 3) (Makarevich et al., 2011; Pivko et al., 2012). The authors in these studies also report that in cows with a very poor body condition (BCS 1) the percentage of ovulated follicles was lower $(19.0 \%)$ than in cows with BCS 2 (76.6\%) or BCS 3 (68.7\%). Sirotkin et al. (2013) doc- 
umented that in cows with a tendency to emaciation (BCS 2) ovarian function may be suppressed by the increased production of the oestradiol hormone.

Kubovičová et al. (2012), using ovaries from 163 cows slaughtered at the abattoir, studied the influence of the animal body condition on the number of follicles on the ovary. The results showed that animals with an optimal body condition (BCS 3 ) had a significantly higher number of follicles per ovary than animals tending to fattening (BCS 4) or an emaciated condition (BCS 1). For each group (BCS 1, BCS 3, BCS 4) the follicle counts were as follows: $13.33 \pm 1.31,18.04 \pm 2.66$ and $5.19 \pm 1.24$ pieces, respectively (Kubovičová et al., 2012). Statistically significant differences were found between BCS 3 and BCS 4. Also, in Polish Friesian cows, Nowak et al. (2011) documented a lower mean number of follicles and aspirated oocytes in extremely emaciated cows.

The relationship of body condition to the quality of aspirated oocytes was also evaluated in relation to the in vitro maturation (IVM) outcome. In various BCS groups (BCS 1 , 2, 3, 4), Kubovičová et al. (2012) observed a higher proportion of maturable oocytes (number of IVM-grade oocytes compared to the total number of collected oocytes; \%) in cows with an optimal body condition than in animals tending to obesity or emaciation. Specifically, the proportion of maturable oocytes was $45.27 \%, 48.97 \%, 61.27 \%$ and $35.48 \%$ for BCS 1, 2, 3 and 4, respectively. Similarly, comparing the proportion of total mature and suitable oocytes for in vitro fertilization (IVF), a higher proportion of oocytes was detected in cows with an optimal body condition (79.85\%, $78.06 \%, 96.13 \%$ and $63.63 \%$, respectively). However, these differences were not statistically significant (Kubovičová et al., 2012).

Another study demonstrated that Holstein cows with an optimal body condition (BCS 3) had a higher quality of aspirated oocytes (oocytes selected for IVM compared to total recovered oocytes; \%) than animals tending to emaciation (Chrenek et al., 2015). The results in the groups BCS 1, 2 and 3 were arranged as follows: $43.60 \%, 57.60 \%$ and $60.90 \%$, respectively. The differences compared to the BCS 1 group were statistically significant. This study also performed the evaluation according to actin grades. Actin cytoskeleton was classified into three quality grades (grade I - the best quality). There were no differences found among body condition groups (BCS 1, 2 and 3) in the proportion of embryos with grade I actin $(41.67 \%, 53.12 \%$ and $42.86 \%)$. However, summer months proved to be an important factor in the actin cytoskeleton quality $(75.00 \%$ of embryos with grade I actin) compared to the autumn or spring season $(35.56 \%$ or $28.57 \%$, respectively) (Chrenek et al., 2015).

The relationship between the body condition and quality of oocytes was also studied by Ruiz et al. (1996). The authors detected a higher proportion of cleaved embryos in cows with an optimal body condition than in animals tending to emaciation. Specifically, the proportion of cleaved embryos in the studied BCS groups (BCS 1, 2 and 3) was 49.1\%, 45.6\% and $61.1 \%$, respectively. Snijders et al. (2000) also found that better oocyte quality was associated with the optimal body condition of cows, particularly in cleavage rates and blastocyst formation. The authors state that in cows with BCS 1.52.5, the average number of collected oocytes was 7.0 \pm 1.8 vs. $8.5 \pm 1.48$ in the BCS 3.3-4.0 group; the cleavage rate was $61.9 \%$ vs. $75.7 \%$ and the blastocyst rate (cultured from oocytes) $3.0 \%$ vs. $9.9 \%$, respectively (Snijders et al., 2000).

The presented studies demonstrate a significant influence of the body condition of cows on their ovarian activity. The abovementioned literary sources are mainly focused on Holstein cattle, but the relationship between the body condition and reproduction traits has also been studied in other breeds, including local breeds. Thus, Fihri et al. (2005) studied the relationship between BCS and ovarian activity in different breeds in Morocco (Oulmès-Zaër breed, Holstein, crossbreeds). They reported a lower number of follicles per ovary and lower oocyte quality in animals with a lower body condition (BCS 2). Particularly, the average number of follicles, 22.98 (17.30, 23.80 and 37.83), was counted in cows with BCS 2, 3 and 5 (overall mean), and the average number of good-quality oocytes was 2.03 (1.07, 2.39 and 4.30, respectively) (Fihri et al., 2005).

Similarly, Domínguez (1995) studied the effect of animal body condition on the follicle number and oocyte quality in 449 cows (zebu, European breed, crossbred). Significant differences were found in the oocyte quality. In cows with BCS 1,3 and 5, $16 \%, 40 \%$ and $42 \%$ of proper-quality oocytes were found, respectively (Domínguez, 1995).

\section{Conclusion}

This review shows a close relationship between the cow body condition and reproduction traits not only from the viewpoint of animal husbandry parameters (e.g., $56 \mathrm{~d}$ nonreturn rate at first insemination, interval to first services, etc.), but also in the relationship to ovarian activity (e.g., oocyte recovery and in vitro embryo production). In general, most authors agree that the worsening of the body condition towards under-condition or over-condition is associated with worse results in embryo transfer (number and quality of embryos) and in vitro procedures (number and quality of aspirated oocytes). Therefore, it is necessary to pay better attention to the body condition of animals because this is an important factor affecting reproduction at the ovarian level.

Data availability. No data sets were used in this article.

Author contributions. JB, AN and EK wrote the draft version of the review; AM wrote Sect. 5 "Body condition of cows from the viewpoint of ovarian activity, oocyte recovery and embryo production in vitro" and critically checked the whole text of the review. 
Competing interests. The authors declare that they have no conflict of interest.

Financial support. This research has been supported by the Palacký University Olomouc (grant no. IGA_PrF_2019_024) and the Slovak Agency for the Support of Science and Technology (grant no. APVV-0137-10).

Review statement. This paper was edited by Steffen Maak and reviewed by R. Filipčík and Oldřich Látal.

\section{References}

Alvarez, J. R., Arroqui, M., Mangudo, P., Toloza J., Jatip, D., Rodríguez, J. M., Teyseyre, A., Sanz, C., Zunino, A., Machado, C., and Mateos, C.: Body condition estimation on cows from depht images using Convolutional Neural Networks, Comput. Electron. Agr., 155, 12-22, https://doi.org/10.1016/j.compag.2018.09.039, 2018.

Aungier, S. P. M., Roche, J. F., Diskin, M. G., and Crowe, M. A.: Risk factors that affect reproductive target achievement in fertile dairy cows, J. Dairy Sci., 97, 3472-3487, https://doi.org/10.3168/jds.2013-7404, 2014.

Azzaro, G., Caccamo, M., Ferguson, J. D., Battiato, S., Farinella, G. M., Guarnera, G. C., Puglisi, G., Petriglieri, R., and Licitra, G.: Objective estimation of body condition score by modeling cow body shape from digital images, J. Dairy Sci., 94, 2126-2137, https://doi.org/10.3168/jds.2010-3467, 2011.

Banos, G., Brotherstone, S., and Coffey, M. P.: Prenatal Maternal Effects on Body Condition Score, Female Fertility, and Milk Yield of Dairy Cows, J. Dairy Sci., 90, 3490-3499, https://doi.org/10.3168/jds.2006-809, 2007.

Bastin, C., Loker, S., Gengler, N., Sewalem, A., and Miglior, F.: Genetic relationships between body condition score and reproduction traits in Canadian Holstein and Ayrshire first-parity cows, J. Dairy Sci., 93, 2215-2228, https://doi.org/10.3168/jds.20092720, 2010.

Beam, S. W. and Butler, W. R.: Energy Balance and Ovarian Follicle Development Prior to the First Ovulation Postpartum in Dairy Cows Receiving Three Levels of Dietary Fat, Biol. Reprod., 56, 133-142, https://doi.org/10.1095/biolreprod56.1.133, 1997.

Bercovich, A., Edan, Y., Alchanatis, V., Moallem, U., Parmet, Y., Honig, H., Maltz, E., Antler, A., and Halachmi, I.: Development of an automatic cow body condition scoring using body shape signature and Fourier descriptors, J. Dairy Sci., 96, 8047-8059, https://doi.org/10.3168/jds.2013-6568, 2013.

Berry, D. P., Buckley, F., Dillon, P., Evans, R. D., Rath, M., and Veerkamp, R. F.: Genetic parameters for body condition score, body weight, milk yield, and fertility estimated using random regression models, J. Dairy Sci., 86, 3704-3717, https://doi.org/10.3168/jds.S0022-0302(03)73976-9, 2003.

Berry, D. P., Lee, J. M., MacDonald, K. A., Stafford, K., Matthews, L., and Roche, J. R.: Associations Among Body Condition Score, Body Weight, Somatic Cell Count, and Clinical Mastitis in Seasonally Calving Dairy Cattle, J. Dairy Sci., 90, 637-648, https://doi.org/10.3168/jds.S0022-0302(07)71546-1, 2007a.
Berry, D. P., Lee, J. M., Macdonald, K. A., and Roche, J. R.: Body Condition Score and Body Weight Effects on Dystocia and Stillbirths and Consequent Effects on Post-calving Performance, J. Dairy Sci., 90, 4201-4211, https://doi.org/10.3168/jds.20070023, 2007b.

Bewley, J. M., Peacock, A. M., Lewis, O., Boyce, R. E., Roberts, D. J., Coffey, M. P., Kenyon, S. J., and Schutz, M. M.: Potential for estimation of body condition scores in dairy cattle from digital images, J. Dairy Sci., 91, 3439-3453, https://doi.org/10.3168/jds.2007-0836, 2008.

Bezdíček, J. and Louda, F.: Reprodukční fyziologie skotu (Reproduction physiology in the cattle breeding), Cattle Research, 58, 20-26, 2016.

Bezdíček, J., Makarevič, A., Stádník, L., Kubovičová, E., Louda, F., Hegedüšová, Z., Holásek, R., Ducháček, J., and Stupka, R.: Analysis of factors affecting the quantity and quality of embryo production in superovulated cows, Züchtungskunde, 87, 249-264, 2015.

Boland, M. P., Lonergan, P., and O'Callaghan, D.: Effect of nutrition on endocrine parameters, ovarian physiology, and oocyte and embryo development, Theriogenology, 55, 13231340, https://doi.org/10.1016/S0093-691X(01)00485-X, 2001.

Buckley, F., O’Sullivan, K., Mee, J. F. Evans, D. R., and Dillon, P.: Relationships Among Milk Yield, Body Condition, Cow Weight, and Reproduction in Spring-Calved Holstein-Friesians, J. Dairy Sci., 86, 2308-2319, https://doi.org/10.3168/jds.S00220302(03)73823-5, 2003.

Cam, M. A., Garipoglu, A. V., and Kirikci, K.: Body condition status at mating affects gestation length, offspring yield and return rate in ewes, Arch. Anim. Breed., 61, 221-228, https://doi.org/10.5194/aab-61-221-2018, 2018.

Carvalho, P. D., Souza, A. H., Amundson, M. C., Hackbart, K. S., Fuenzalida, M. J., Herlihy, M. M., Ayres, H., Dresch, A. R., Vieira, L. M., Guenther, J. N., Grummer, R. R., and Fricke, P. M.: Relationships between fertility and postpartum changes in body condition and body weight in lactating dairy cows, J. Dairy Sci., 97, 3666-3683, https://doi.org/10.3168/jds.2013-7809, 2014.

Chebel, R. C., Mendonça, L. G. D., and Baruselli, P. S.: Association between body condition score change during the dry period and postpartum health and performance, J. Dairy Sci., 101, 45954614, https://doi.org/10.3168/jds.2017-13732, 2018.

Chrenek, P., Kubovičová, E., Olexíková, L., Makarevich, A. V., Toporcerová, S., and Ostró, A.: Effect of body condition and season on yield and quality of in vitro produced bovine embryos, Zygote, 23, 893-899, https://doi.org/10.1017/S0967199414000604, 2015.

Dechow, C. D., Rogers, G. W., and Clay, J. S.: Heritabilities and correlations among body condition scores, production traits, and reproductive performance, J. Dairy Sci., 84, 266-275, https://doi.org/10.3168/jds.S0022-0302(01)74476-1, 2001.

Dechow, C. D., Rogers, G. W., and Clay, J. S.: Heritability and correlations among body condition score loss, body condition score, production and reproductive performance, J. Dairy Sci., 85, 3062-3070, https://doi.org/10.3168/jds.S00220302(02)74393-2, 2002.

Domecq, J. J., Skidmore, A. L., Lloyd, J. W., and Kaneene, J. B.: Relationship between body condition scores and conception at first artificial insemination in a large dairy herd 
of high yielding Holstein cows, J. Dairy Sci., 80, 113-120, https://doi.org/10.3168/jds.S0022-0302(97)75918-6, 1997.

Domínguez, M. M.: Effect of body condition, reproductive status and breed on follicular population and oocyte quality in cows, Theriogenology, 43, 1405-1418, https://doi.org/10.1016/0093691X(95)00126-S, 1995.

Edmonson, A. J., Lean, I. J., Weaver, L. D., Farver, T., and Webster, G.: A body Condition Scoring Chart for Holstein Dairy Cows, J. Dairy Sci., 72, 68-78, https://doi.org/10.3168/jds.S00220302(89)79081-0, 1989.

Ferguson, J. D., Galligan, D. T., and Thomsen, N.: Principal descriptors of body condition score in holstein cows, J. Dairy Sci., 77, 2695-2703, https://doi.org/10.3168/jds.S00220302(94)77212-X, 1994.

Ferguson, J. D., Azzaro, G., and Licitra, G.: Body condition assessment using digital images, J. Dairy Sci., 89, 3833-3841, https://doi.org/10.3168/jds.S0022-0302(06)72425-0, 2006.

Fihri, F. A., Klakhdissi,H., Derqaoui, H., Hajji, Kh., Naciri, M., and Goumari, A.: Genetic and nongenetic effects on the number of ovarian follicles and oocyte yield and quality in the bovine local (Oulmes Zaer), exotic breeds and their crosses in Morocco, Afr. J. Biotechnol., 4, 9-13, 2005.

Friggens, N. C., Ingvartsen, K. L., and Emmans, G. C.: Prediction of Body Lipid Change in Pregnancy and Lactation, J. Dairy Sci., 87, 988-1000, https://doi.org/10.3168/jds.S0022-0302(04)73244-0, 2004.

Gillund, P., Reksen, O., Grohn, Y. T., and Karlberg, K.: Body condition related to ketosis and reproductive performance in Norwegian dairy cows, J. Dairy Sci., 84, 1390-1396, https://doi.org/10.3168/jds.S0022-0302(01)70170-1, 2001.

Gruber, L., Ledinek, M., Steininger, F., Fuerst-Waltl, B., Zottl, K., Royer, M., Krimberger, K., Mayerhofer, M., and EggerDanner, C.: Body weight prediction using body size measurements in Fleckvieh, Holstein, and Brown Swiss dairy cows in lactation and dry periods, Arch. Anim. Breed., 61, 413-424, https://doi.org/10.5194/aab-61-413-2018, 2018.

Halachmi, I., Polak, P., Roberts, D. J., and Klopcic, M.: Cow Body Shape and Automation of Condition Scoring, J. Dairy Sci., 91, 4444-4451, https://doi.org/10.3168/jds.2007-0785, 2008.

Hansen, M. F., Smith, M. L., Smith, L. N., Jabbar, K. A., and Forbes, D.: Automated monitoring of dairy cow body condition, mobility and weight using a single $3 \mathrm{D}$ video capture device, Comput. Ind., 98, 14-22, https://doi.org/10.1016/j.compind.2018.02.011, 2018.

Kadokawa, H., Tameoka, N., Uchiza, M., Kimura, Y., and Yonai, M. A.: Field Study on the Relationship Between Body Condition and Embryo Production in Superovulated Holstein Yearling Heifers, J. Dairy Sci., 91, 1087-1091, https://doi.org/10.3168/jds.20070642, 2008.

Koenen, E. P. C., Veerkamp, R. F., Dobbelaar, P., and De Jong, G.: Genetic analysis of body condition score of lactating Dutch Holstein and Red-and-White heifers, J. Dairy Sci., 84, 1265-1270, https://doi.org/10.3168/jds.S0022-0302(01)74588-2, 2001.

Kubovičová, E., Makarevič, A., Hegedušová, Z., Slezáková, M., and Bezdíček, J.: Effect of body condition score on oocyte yield and in vitro embryo development, Cattle Research, 54, 17-22, 2012.

Kuźnicka, E., Rant, W., Radzik-Rant, A., Kunowska-Slósarz, M., and Balcerak, M.: The ovulation rate, plasma progesterone and estradiol concentration, and litter size of a local ewe breed kept in a barn vs. those kept under an overhead shelter, Arch. Anim. Breed., 59, 145-150, https://doi.org/10.5194/aab-59-145-2016, 2016.

Ledinek, M., Gruber, L., Steininger, F., Fuerst-Waltl, B., Zottl, K., Royer, M., Krimberger, K., Mayerhofer, M., and EggerDanner, C.: Analysis of lactating cows on commercial Austrian dairy farms: the influence of genotype and body weight on efficiency parameters, Arch. Anim. Breed., 62, 491-500, https://doi.org/10.5194/aab-62-491-2019, 2019.

Loker, S., Miglior, F., Koeck, A., Neuenschwander, T. F. O., Bastin, C., Jamrozik, J., and Schaeffer, L. R.: Relationship between body condition score and health traits in firstlactation Canadian Holsteins, J. Dairy Sci., 95, 6770-6780, https://doi.org/10.3168/jds.2012-5612, 2012.

Makarevich, A. V., Pivko, J., Kubovičová, E., Hegedušová, Z., and Louda, F.: Ovarian follicle atresia in dairy cows in relation to the body condition, Journal of Microbiology, Biotechnology and Food Sciences, 1, 426-436, 2011.

Makarevich, A. V., Kubovičová, E., Hegedüšová, Z., Bezdíček, J., Louda, F., and Pivko, J.: Impact of body condition of dairy cows on ovarian state and oocyte quality, Book of Abstracts and poster presentation, in: 17th International Congress on Biotechnology in Animal Reproduction (ICBAR), Leipzig, Germany, 12-14 October 2012a.

Makarevich, A., Kubovičová, E., Olexiková, L., Hegedušová, Z., and Chrenek, P.: Influence of body condition of dairy cows on the oocyte and embryo quality in vitro, in: The 16th ESDAR Conference, Dublin, Ireland, 29 August-1 September 2012, Reproduction in Domestic Animals, 47, p. 65, 2012b.

Makarevich, A. V., Špaleková, E., Stádník, L., Bezdíček, J., and Kubovičová, E.: Functional characteristics of bovine spermatozoa in relation to the body condition score of bulls, Slovak Journal of Animal Science (SJAS), 51, 1-7, 2018.

Murphy, M. G., Enright, W. J., Crowe, M. A., McConnell, K., Spicer, L. J., Boland, M. P., and Roche, J. F.: Effect of dietary intake on pattern of growth of dominant follicles during the oestrous cycle in beef heifers, J. Reprod. Fertil., 92, 333-338, https://doi.org/10.1530/jrf.0.0920333, 1991.

Nowak, T. A., Jaškowski, J. M., Szczepankiewicz, D., and Olechnowicz, J.: Quality and number of cumulus-oocyte complexes (COC) and concentrations of leptin and ghrelin in blood and follicular fluid depending on the body condition of cows, Medycyna Weterynaryjna, 67, 115-119, 2011.

Oba, M., Miyashita, S., Nishii, R., Koiwa, M., Koyama, H., Ambrose, D. J., and Dochi, O.: Short communication: Effects of serum obtained from dairy cows with low or high body condition score on in vitro embryo development, J. Dairy Sci., 96, 16681671, https://doi.org/10.3168/jds.2012-5886, 2013.

Pivko, J., Makarevich, A. V., Kubovičová, E., Ostro, A., Hegedusova, Z., and Louda F.: Histopathological alterations in the antral ovarian follicels in dairy cows with a tendency to emaciation, Histol. Histopathol., 27, 1211-1217, 2012.

Pryce, J. E., Coffey, M. P., and Simm, G.: The Relationship Between Body Condition Score and Reproductive Performance, J. Dairy Sci., 84, 1508-1515, https://doi.org/10.3168/jds.S00220302(01)70184-1, 2001.

Pryce, J. E., Coffey, M. P., Brotherstone, S. H., and Woolliams, J. A.: Genetic relationships between calving inter- 
val and body condition score conditional on milk yield, J. Dairy Sci., 85, 1590-1595, https://doi.org/10.3168/jds.S00220302(02)74229-X, 2002.

Ptáček, M., Ducháček, J., Stádník, L., Hakl, J., and Fantová, M.: Analysis of multivariate relations among birth weight, survivability traits, growth performance, and some important factors in Suffolk lambs, Arch. Anim. Breed., 60, 43-50, https://doi.org/10.5194/aab-60-43-2017, 2017.

Qu, Y., Fadden, A. N., Traber, M. G., and Bobe, G.: Potential risk indicators of retained placenta and other diseases in multiparous cows, J. Dairy Sci., 97, 4151-4165, https://doi.org/10.3168/jds.2013-7154, 2014.

Roche, J. R., Lee, J. M., MacDonald, K. A., and Berry, D. P.: Relationships among body condition score, body weight, and milk production variables in pasture-based dairy cows, J. Dairy Sci., 90, 3802-3815, https://doi.org/10.3168/jds.2006-740, 2007.

Ruiz, L. L., Alvarez, N., Nunez, I., Montes, I., Solano, R., Fuentes, D., Pedroso, R., Palma, G. A., and Brem, G.: Effect of body condition on the developmental competence of IVM/IVF bovine oocytes, Theriogenology, 45, 292-296, 1996.

Shelley, A. N., Lau, D. L., Stone, A. E., and Bewley, J. M.: Short communication: Measuring feed volume and weight by machine vision, J. Dairy Sci., 99, 386-391, https://doi.org/10.3168/jds.2014-8964, 2016.

Shigeta, M., Ike, R., Takemura, H., and Ohwada, H.: Automatic Measurement and Determination of Body Condition Score of Cows Based on 3D Images Using CNN, Journal of Robotics and Mechatronics, 30, 206-213, https://doi.org/10.20965/jrm.2018.p0206, 2018.

Silke, V., Diskin, M. G., Kenny, D. A., Boland, M. P., Dillon, P., Mee, J. F., and Sreenan, J. M.: Extent, pattern and factors associated with late embryonic loss in dairy cows, Anim. Reprod. Sci., 71, 1-12, https://doi.org/10.1016/S0378-4320(02)00016-7, 2002.
Sirotkin, A. V., Makarevich, A. V., Makovicky, P., and Kubovicova, E.: Ovarian, metabolic and endocrine indexes in dairy cows with different body condition scores, J. Anim. Feed Sci., 22, 316-322, https://doi.org/10.22358/jafs/65919/2013, 2013.

Snijders, S. E., Dillon, P., O'Callaghan, D., and Boland, M. P.: Effect of genetic merit, milk yield, body condition and lactation number on in vitro oocyte development in dairy cows, Theriogenology, 53, 981-989, https://doi.org/10.1016/S0093691X(00)00244-2, 2000.

Spoliansky, R., Edan, Y., Parmet, Y., and Halachmi, I.: Development of automatic body condition scoring using a low-cost 3-dimensional Kinect camera, J. Dairy Sci., 99, 7714-7725, https://doi.org/10.3168/jds.2015-10607, 2016.

Tančin, V., Mikláš, Š., and Mačuhová, L.: Possible physiological and environmental factors affecting milk production and udder health of dairy cows: A review, Slovak J. Anim. Sci., 51, 32-40, 2018.

Tiezzi, F., Maltecca, C., Cecchinato, A., Penasa, M., and Bittante, G.: Thin and fat cows, and the nonlinear genetic relationship between body condition score and fertility, J. Dairy Sci., 96, 67306741, https://doi.org/10.3168/jds.2013-6863, 2013.

Weber, A., Salau, J., Haas, J. H., Junge, W., Bauer, U., Harms, J., Suhr, O., Schönrock, K., Rothfuß, H., and Bieletzki, S.: Estimation of backfat thickness using extracted traits from an automatic 3D optical system in lactating Holstein-Friesian cows, Livest Sci., 165, 129-137, https://doi.org/10.1016/j.livsci.2014.03.022, 2014.

Wildman, E. E., Jones, G. M., Wagner, P. E., Boman, R. L., Troutt, H. F., and Lesch, T. N.: A dairy cow body condition scoring system and its relationship to selected production characteristics, J. Dairy Sci., 65, 495-501, https://doi.org/10.3168/jds.S00220302(82)82223-6, 1982. 